\title{
Neuroprotective Properties of Resveratrol and Its Derivatives-Influence on Potential Mechanisms Leading to the Development of Alzheimer's Disease
}

\author{
Michał Wiciński, Anna Domanowska, Eryk Wódkiewicz $@$ and Bartosz Malinowski * \\ Department of Pharmacology and Therapeutics, Faculty of Medicine, Collegium Medicum in Bydgoszcz, \\ Nicolaus Copernicus University, M. Curie 9, 85-090 Bydgoszcz, Poland; wicinski4@wp.pl (M.W.); \\ a.domanowska@o2.pl (A.D.); eryk.wodkiewicz09@gmail.com (E.W.) \\ * Correspondence: bartosz.malin@gmail.com
}

Received: 9 March 2020; Accepted: 11 April 2020; Published: 15 April 2020

check for updates

\begin{abstract}
The lack of effective Alzheimer's disease treatment is becoming a challenge for researchers and prompts numerous attempts to search for and develop better therapeutic solutions. Compounds that affect several routes of the neurodegeneration cascade leading to the development of disease are of particular interest. An example of such substances is resveratrol and its synthetic and natural derivatives, which have gained popularity in recent years and show promise as a possible new therapeutic option in the approach to Alzheimer's disease treatment. In this article, the state of the art evidence on the role of resveratrol (RSV) in neuroprotection is presented; research results are summarized and the importance of resveratrol and its derivatives in the treatment of Alzheimer's disease are underlined. It also focuses on various modifications of the resveratrol molecule that should be taken into account in the design of future research on drugs against Alzheimer's disease.
\end{abstract}

Keywords: resveratrol; Gnetin C; Alzheimer's disease; neuroprotection

\section{Introduction}

Alzheimer's disease (AD) became more common in an aging society. In the United States, it is estimated that the number of Alzheimer's disease patients in 2050 will be almost 14 million [1] and over 100 million in the world [2]. Acetylcholinesterase inhibitors (rivastigmine, galantamine, donepezil) and N-methyl-D-aspartate (NMDA) receptor antagonist (memantine) are the only drugs approved by the Food and Drug Administration (FDA) for Alzheimer's disease treatment so far. The effect of the inhibitors is based on the growth of acetylcholine in the central nervous system (CNS), while in the memantine, by blocking NMDA receptors, neurons are protected from excessive stimulation that could damage them [3]. However, it does not prevent neurodegenerative processes leading to accelerated atrophy of nerve cells responsible for the symptoms of the disease [4]. The dominant feature of the clinical picture of people affected by Alzheimer's disease is early memory loss, which is accompanied by cognitive and behavioral disorders as the disease progresses [5]. The lack of effective Alzheimer's disease treatment is becoming a challenge for researchers and has prompted numerous attempts to develop better therapeutic solutions in this area. There is great interest in drugs that affect not just one but several routes of the neurodegeneration cascade [6].

\section{A $\beta$ Peptides and Tau Protein}

Histologically, Alzheimer's disease is characterized by the presence of extracellular amyloid plaques and intracellular tangles of neurofibrillary plexuses (NFT) in certain specific areas of the brain, such as the hippocampus and association cortex of the frontal, parietal and temporal lobes $[7,8]$. 
The exact etiology of Alzheimer's disease is not fully understood but more and more research suggests that it is a multifactorial disease [6] in which toxic A $\beta$ aggregation [9], neuroinflammation [10], tau protein hyperphosphorylation and oxidative stress play a key role [11]. It is assumed that the key neurotoxicity inducers are not, as previously thought, large, insoluble deposits of amyloid and NFT, but soluble, nonfibrillar intermediate oligomeric forms of $\mathrm{A} \beta$ peptide and tau protein, which in the process of aggregation lead to disorders at the synaptic level and progressive and accelerated apoptosis of neurons [12,13]. Interestingly, researchers found that tau oligomers have the ability to enter cells and inoculate pathological aggregation of intracellular tau. What's more, it is possible to transfer them between cells in a prion-like mechanism. This creates a chance for further induction of false folding in healthy neurons and the spread of pathology in the brain. Amyloid oligomers have similar properties, they can inoculate and stimulate monomer aggregation and lead to the formation of neurotoxic oligomers. In addition, they have a special effect on the conversion of monomeric tau to toxic tau oligomer, which initiates the cascade of events in Alzheimer's disease [11-13].

$\mathrm{A} \beta$ peptides are produced from amyloid precursor protein (APP), which is an integral type I membrane protein, by a proteolytic route in the so-called amyloidogenic pathway using $\beta$-secretase 1 (BACE 1) and $\gamma$-secretase [14]. Recent studies have reported that the blocking of BACE1 activity may prevent the progression of cerebral amyloid angiopathy associated with abnormalities in small brain vessels caused by A $\beta$ aggregation [15]. Resveratrol (3,5, $4^{\prime}$-trihydroxy-trans-stilbene), a polyphenol contained in red wine, peanuts, and some berries, is known for its anti-atherosclerotic, anti-inflammatory, antioxidant, and longevity-promoting properties [16]. There is ample evidence of its neuroprotective effects (Table 1).

Table 1. Neuroprotective properties of resveratrol in animal and human studies.

\begin{tabular}{|c|c|c|c|}
\hline Subject of the Study & Dose & Effect & Reference \\
\hline $\begin{array}{l}\text { Streptozotocin-induced } \\
\text { Alzheimer's dementia model } \\
\text { in Wistar rats }\end{array}$ & $\begin{array}{l}10 \text { i } 20 \mathrm{mg} / \mathrm{kg} \text { of } \\
\text { resveratrol per day i.p. }\end{array}$ & $\uparrow$ glutathione in brain & [17] \\
\hline $\begin{array}{c}\text { Sprague-Dawley rats } \\
\text { with AD }\end{array}$ & $100 \mu \mathrm{M}$ i.c.v. & $\begin{array}{c}\uparrow \mathrm{HO}-1 \\
\downarrow \text { iNOS } \\
\text { in hippocampus }\end{array}$ & [18] \\
\hline ICR mice with AD & $\begin{array}{l}40 \mathrm{mg} / \mathrm{kg} \text { of resveratrol } \\
\text { per day }\end{array}$ & $\begin{array}{c}\downarrow \text { PDE4A5,4B1,4D3 } \\
\text { expression } \\
\uparrow \mathrm{BDNF} \\
\uparrow \mathrm{pCREB} \\
\uparrow \mathrm{PKA} \\
\uparrow \mathrm{BCl}-2 \text { expression } \\
\downarrow \mathrm{BAX} \text { expression } \\
\downarrow \mathrm{IL}-1 \beta, \mathrm{IL}-6 \\
\text { in hippocampus }\end{array}$ & [19] \\
\hline $\begin{array}{l}\text { People with mild or } \\
\text { moderate AD }\end{array}$ & $\begin{array}{l}\max 2 \mathrm{~g} / \text { day of } \\
\text { resveratrol }\end{array}$ & $\begin{array}{l}\downarrow \mathrm{A} \beta 40 \text { in plasma and in } \\
\text { cerebrospinal fluid } \\
\text { resveratrol safe and } \\
\text { well tolerated }\end{array}$ & [20] \\
\hline $\begin{array}{l}\text { People with mild or } \\
\text { moderate } \mathrm{AD}\end{array}$ & $\begin{array}{l}\max 2 \mathrm{~g} / \text { day of } \\
\text { resveratrol }\end{array}$ & $\begin{array}{c}\downarrow \text { MMP-9 in } \\
\text { cerebrospinal fluid }\end{array}$ & [21] \\
\hline $\begin{array}{l}\text { Healthy overweight elderly } \\
\text { man }\left(\text { BMI } 25-30 \mathrm{~kg} / \mathrm{m}^{2}\right)\end{array}$ & $\begin{array}{c}200 \mathrm{mg} / \text { day of resveratrol } \\
320 \mathrm{mg} \text { of quercetin }\end{array}$ & $\begin{array}{c}\uparrow \text { memory performance } \\
\uparrow \text { functional connectivity (FC) } \\
\text { of the hippocampus } \\
\downarrow \text { HbA1c in serum }\end{array}$ & [22] \\
\hline $\begin{array}{l}\text { People with mild or } \\
\text { moderate AD }\end{array}$ & $\begin{array}{c}5 \mathrm{mg} \text { resveratrol } \\
5 \mathrm{~g} \text { malate } \\
5 \mathrm{~g} \text { dextrose/twice a day }\end{array}$ & $\begin{array}{l}\text { resveratrol safe and } \\
\text { well tolerated }\end{array}$ & [23] \\
\hline
\end{tabular}


Table 1. Cont.

\begin{tabular}{|c|c|c|c|}
\hline Subject of the Study & Dose & Effect & Reference \\
\hline Wistar rats & $\begin{array}{c}10 \mathrm{mg} / \mathrm{kg} \text { of resveratrol } \\
\text { per day }\end{array}$ & $\uparrow$ serum BDNF & [24] \\
\hline $\begin{array}{l}\mathrm{A} \beta \mathrm{PP} / \mathrm{PS} 1 \text { mouse model } \\
\text { of } \mathrm{AD}\end{array}$ & $\begin{array}{l}16 \mathrm{mg} / \mathrm{kg} \text { of resveratrol } \\
\text { per day }\end{array}$ & $\begin{array}{c}\uparrow \text { synaptophysin } \\
\uparrow \text { mitochondrial IV complex } \\
\text { protein in brain }\end{array}$ & [25] \\
\hline $\begin{array}{l}\text { Mouse model of } A D \text { induced } \\
\text { by } A \beta 1-42\end{array}$ & $\begin{array}{c}0.02 \mathrm{mg} / \mathrm{kg} \text { of resveratrol } \\
\text { per day for cerebral } \\
\text { ventricle }\end{array}$ & $\begin{array}{c}\uparrow A M P K \\
\uparrow P G C-1 \\
\downarrow N F-\kappa B / I L-1 \beta / \text { NLRP3 in } \\
\text { hippocampus and } \\
\text { prefrontal cortex }\end{array}$ & [26] \\
\hline $\begin{array}{l}\text { Triple-transgenic mouse } \\
\text { model of AD }(3 \times \mathrm{Tg}-\mathrm{AD})\end{array}$ & $\begin{array}{c}100 \mathrm{mg} / \mathrm{kg} \text { of resveratrol } \\
\text { per day }\end{array}$ & $\begin{array}{c}\uparrow \text { neprilisine } \\
\downarrow \text { BACE1 } \\
\uparrow \text { AMPK } \\
\uparrow \text { PGC- } 1 \\
\uparrow p C R E B \text { in hippocampus }\end{array}$ & [27] \\
\hline $\begin{array}{l}\text { APP/PS1 mouse model } \\
\text { of AD }\end{array}$ & $\begin{array}{c}350 \mathrm{mg} / \mathrm{kg} \text { resveratrol } \\
\text { once a day }\end{array}$ & $\begin{array}{l}\text { inhibition of microglia } \\
\text { activation by } A \beta \text { in brain }\end{array}$ & [28] \\
\hline \multicolumn{4}{|c|}{ 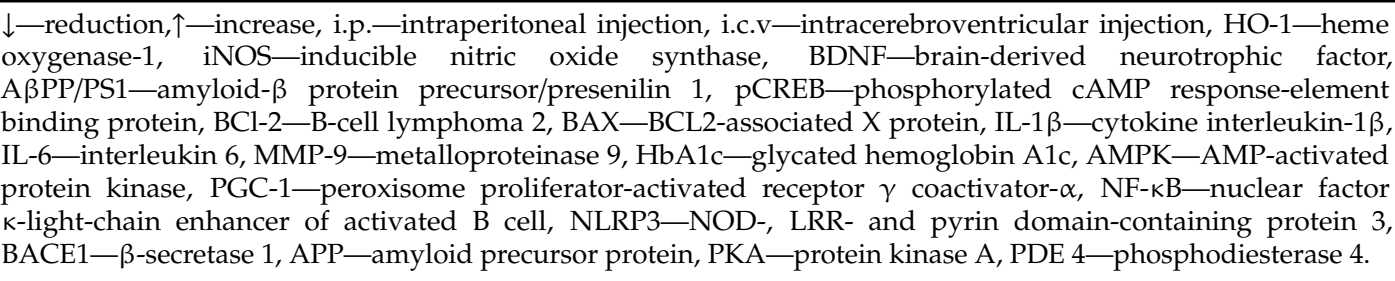 } \\
\hline
\end{tabular}

Resveratrol has been shown to be particularly useful for the treatment of disorders such as Alzheimer's disease [16] because it prevents hippocampal neurodegeneration [29] and cognitive deficits [17]. Choi et al. investigated the effect of resveratrol and its oligomers isolated from Paeonia lactiflora seed on beta-site APP-cleaving enzyme 1 (BACE-1) activity in vitro. $\beta$-secretase is an enzyme of the amyloidogenic pathway, it cuts the amyloid precursor protein (APP) and thus provides the brain with toxic $\beta$-amyloid. All compounds isolated from Paeonia lactiflora seeds, including resveratrol $\left(\mathrm{IC}_{50}=11.9 \mu \mathrm{M}\right)$ proved to be effective inhibitors of $\beta$-secretase in vitro. Resveratrol trimers, gnetin $\mathrm{H}\left(\mathrm{IC}_{50}=0.34 \mu \mathrm{M}\right)$ and suffruticosol $\mathrm{B}\left(\mathrm{IC}_{50}=0.88 \mu \mathrm{M}\right)$, were distinguished by particularly high $\beta$-secretase inhibiting activity [30]. In turn, other researchers assessed the effect of resveratrol at a concentration of $10-40 \mu \mathrm{M}$ on the metabolism of APP in mouse neuroblastoma N2a cells expressing wild type or Swedish $\mathrm{APP}_{695}$. The presence of resveratrol did not change the level of APP and its C-terminal fragments C99, C89, and C83. Moreover, in cell-free tests in vitro and in culture, resveratrol did not inhibit the formation of $\beta$-amyloid. This suggests that resveratrol may not prevent $A \beta$ formation because it does not affect $\beta$ and $\gamma$-secretase activity [31]. Porquet et al. in their research used the mouse familial AD model A $\beta$ PP/PS1 (amyloid- $\beta$ protein precursor/presenilin 1). Resveratrol at a dose of $16 \mathrm{mg} / \mathrm{kg} /$ day was administered to A $\beta \mathrm{PP} / \mathrm{PS} 1$ mice for 10 months, resulting in improved short-term memory in the object recognition test and a significant increase in the presynaptic protein synaptophysin, which may be an expression of improved synaptic activity. Furthermore, a significant increase in mitochondrial IV complex protein has been observed in the brain of the A $\beta$ PP/PS1 mouse, which reflects mitochondrial function and constitutes neuroprotection. It is also worth noting that resveratrol treatment led to a decrease in $\beta$-secretase concentration $(p<0.05)$, without affecting A $\beta$ PP, C99, and C83 [25]. Recent reports indicate that treatment with resveratrol significantly reduces the level of amyloidogenic $\beta$-secretase in mouse strains, including 3xTg-AD and non-transgenic NoTg. In addition, resveratrol contributed to an increase in the activity of the neprilysin enzyme responsible for the degradation of $A \beta$ and promoted the increase of AMP-activated protein kinase (AMPK), peroxisome 
proliferator-activated receptor $\gamma$ coactivator- $\alpha$ (PGC-1 $\alpha$ ) and phosphorylated cAMP response-element binding protein (p-CREB) in both mouse strains, which proves its neuroprotective properties [27].

Feng et al. suggest that the presence of hydroxyl groups in the resveratrol molecule and the hydrophobic interaction between resveratrol and $A \beta 42$ may block the formation of $A \beta 42$ fibers, but not oligomerization. Nevertheless, the authors postulate that resveratrol may have a beneficial effect on the conformation of $A \beta 42$ oligomers and weaken their cytotoxicity. In the presence of resveratrol, the survival of SY5Y neuroblastoma cells exposed to A $\beta 42$ oligomers was significantly higher. This effect is seen in the possibility of the direct binding of resveratrol to $A \beta 42$ and the formation of oligomers with lower toxicity [32]. Li et al. noted the relationship between $A \beta$ oligomers and cellular prion protein $(\mathrm{PrPC})$ in disrupting the synaptic plasticity of the hippocampus. Studies in AD mice and brain tissue have confirmed the ability of soluble $\mathrm{A} \beta$ oligomers to bind to cellular prion protein. In contrast, the use of anti-PrPC antibodies did not impair LTP (long-term synaptic enhancement) in the presence of soluble $A \beta$ oligomers. This suggests the involvement of PrPC in synaptotoxicity associated with $A \beta$ oligomers [33]. Sengupta et al. in their work emphasize that $A \beta$ oligomers act as seeds for various proteins, including PrPC, leading to the formation of toxic aggregates. Normal prion protein (PrPC) is located on the surface of the cell membrane, mainly brain neurons. In the process of incorrect folding of the cellular prion protein (PrPC), an infectious prion protein called scrapie (PrPsc) is formed, which can travel between cells and convert PrPC to PrPSC. The pathological PrPSC prion protein has a $\beta$-sheet structure, and its important feature is its ability to aggregate. Amyloid $\beta, \alpha$-synuclein and tau show similarity in structure and properties to prions and the propagation of incorrect folding of proteins can occur through similar mechanisms leading to the degeneration of the neural network [34].

The non-amyloidogenic route of amyloid precursor protein (APP) processing by $\alpha$-secretase is an alternative to the amyloidogenic route; the activity of $\alpha$-secretase results in soluble APPa product (APPs $\alpha)$, which is assigned neuroprotective properties [35]. The promotion of $\alpha$-secretase activity seems to be beneficial in the prevention and maybe even treatment of Alzheimer's disease, as it may counteract the formation of neurotoxic $A \beta$ [36]. A special role in the protection of neurons against apoptosis is attributed to the nicotinamide adenine dinucleotide $\mathrm{NAD}(+)$-dependent histone deacetylase SIRT1 (Sirtuin-1) [37], which regulates the function of many important transcription factors such as p53, NF- $\mathrm{kB}$ (nuclear factor $\mathrm{k}$-light-chain enhancer of activated B cells), and FOXO (forehead box protein O) [38,39]. Moreover, SIRT1 has been shown to reduce the deposition of A $\beta$ due to the activation of APP processing by non-amyloidogenic pathways [40]. One of the SIRT1 activators is resveratrol [41]. A trend towards increased serum SIRT concentration was recorded in a four-week study giving rats $10 \mathrm{mg} / \mathrm{kg} /$ day of resveratrol per day ( $p=0.011$ compared to placebo) [42]. Resveratrol through SIRT-1 may lead to reduced A $\beta 42$-induced neuroinflammation due to inhibition of the NF- $\mathrm{KB}$ [43] signal pathway and removal of free radicals [44].

Reduced SIRT-1 levels in the brains of Alzheimer's disease patients are associated with the accumulation of $A \beta$ and tau [45]. Tau is a microtubule-bound protein that provides normal neuronal function, but if it is not properly dephosphorylated it polymerizes into helical fibers forming neurofibrillary plexuses (NFT) [46]. It has been demonstrated that tau acetylation provides protection against degradation of hyperphosphorylated tau and the presence of SIRT 1 is an important factor leading to in vitro and in vivo tau deacetylation [47]. Resveratrol via SIRT-1 can, therefore, be expected to reduce the level of hyperphosphorylated tau and provide protection against neurodegeneration. In addition, it has been noted that resveratrol by lowering the expression of MID1 ubiquitin ligase increases protein phosphatase 2A (PP2A) activity and promotes tau dephosphorylation by preventing its accumulation [48].

\section{Oxidative-Nitrosative Stress}

It is believed that the first factor preceding the appearance of pathological changes characteristic for Alzheimer's disease is oxidative damage to cellular structures [49]. Oxidative stress, and especially lipid peroxidation, seems to be molecular pathways involved in the early stages of the disease [50]. 
It has been found out that oxidative stress induces BACE1 expression in a mechanism dependent on $\gamma$-secretase activity through the c-jun $\mathrm{N}$-terminal kinase JNK/c-jun pathway, thereby enhancing the production of $A \beta$ peptides; while, $A \beta$ intensifies oxidative stress, which leads to the formation of a so-called vicious circle [51]. In the presence of oxidative stress, superoxide anions are also produced by neuronal nitric oxide synthase (nNOS), which then react with NO generating reactive nitrogen species in the form of peroxynitrites with strong oxidizing properties [52]. There is evidence that $A \beta$ through oxidative-nitrosative stress leads to the damage of brain endothelial cells DNA (deoxyribonucleic acid) [53]. It is suggested that the improvement of spatial memory of rats with Alzheimer's disease, treated with resveratrol, is the result of its ability to effectively reduce the level of oxidative stress and protect neurons from apoptosis. This study showed that resveratrol abolishes $A \beta$-induced lipid peroxidation and expression of heme oxygenase-1 (HO-1) reduction; these effects are attributed to resveratrol's ability to reduce inducible nitric oxide synthase (iNOS) levels in the hippocampus [18].

Wang et al. report that improved memory performance in AD mice treated with resveratrol may be associated with the inhibition of phosphodiesterase 4 (PDE4) subtypes A5, 4B1, and 4D3 expression and a subsequent increase in activation of the cAMP/PKA (protein kinase A) pathway. Furthermore, increased cAMP (cyclic adenosine monophosphate) activity may mediate in the reduction of neuronal neuroinflammation and apoptosis. After three weeks of administration of $40 \mathrm{mg} / \mathrm{kg}$ resveratrol to AD mice, statistically significant reductions in the levels of pro-inflammatory cytokines IL-1 $\beta$ and IL-6, an increase in BCl-2 antiapoptotic protein expression, and a decrease in Bax (BCL2-associated X protein) proapoptotic protein expression were achieved. In addition, resveratrol has been shown to eliminate the negative effects of $A \beta 42$ on phosphorylated cAMP binding protein (pCREB) and brain-derived neurotrophic factor (BDNF), which ultimately results in memory enhancement in mice and speaks for the neuroprotective effect of resveratrol [19]. This polyphenol, administered orally to healthy rats at a dose of $10 \mathrm{mg} / \mathrm{kg}$ for four weeks, also increases BNDF levels. The study showed a significant increase in BNDF concentration $(1.64 \pm 0.31 \mathrm{ng} / \mathrm{mL}, p=0.031)$ in the serum compared to the control group $(1.32 \pm 0.26 \mathrm{ng} / \mathrm{mL})$. In addition, it has been shown that resveratrol can directly reduce contractility of smooth muscle cells in rat tail arteries in a manner independent of endothelial NO synthase (NOS-3). Thanks to such properties, resveratrol can have positive effects on maintaining stable cerebral blood flow and thus prevent neuronal damage and cognitive function deficits [24]. Resveratrol administered in the cerebral ventricle at a dose of $0.02 \mathrm{mg} / \mathrm{kg} /$ day improves memory and reverses $A \beta$-induced changes in the inflammatory response and mitochondrial dysfunction. Researchers achieved a significant reduction in the levels of NF- $\mathrm{kB}$ (nuclear factor $\mathrm{k}$-light-chain enhancer of activated B cell), interleukin $1 \beta$ and NLRP3 (NOD-, LRR- and pyrin domain-containing protein 3 ) inflammation markers in the hippocampus and cortex of mouse with AD. AMP-activated protein kinase (AMPK) and peroxisome proliferator-activated receptor $\gamma$ coactivator- $\alpha$ (PGC-1 $\alpha$ ) activities that are involved in mitochondrial biogenesis have also increased [26]. The simplified diagram with possible mechanisms of resveratrol is presented in Figure 1. 


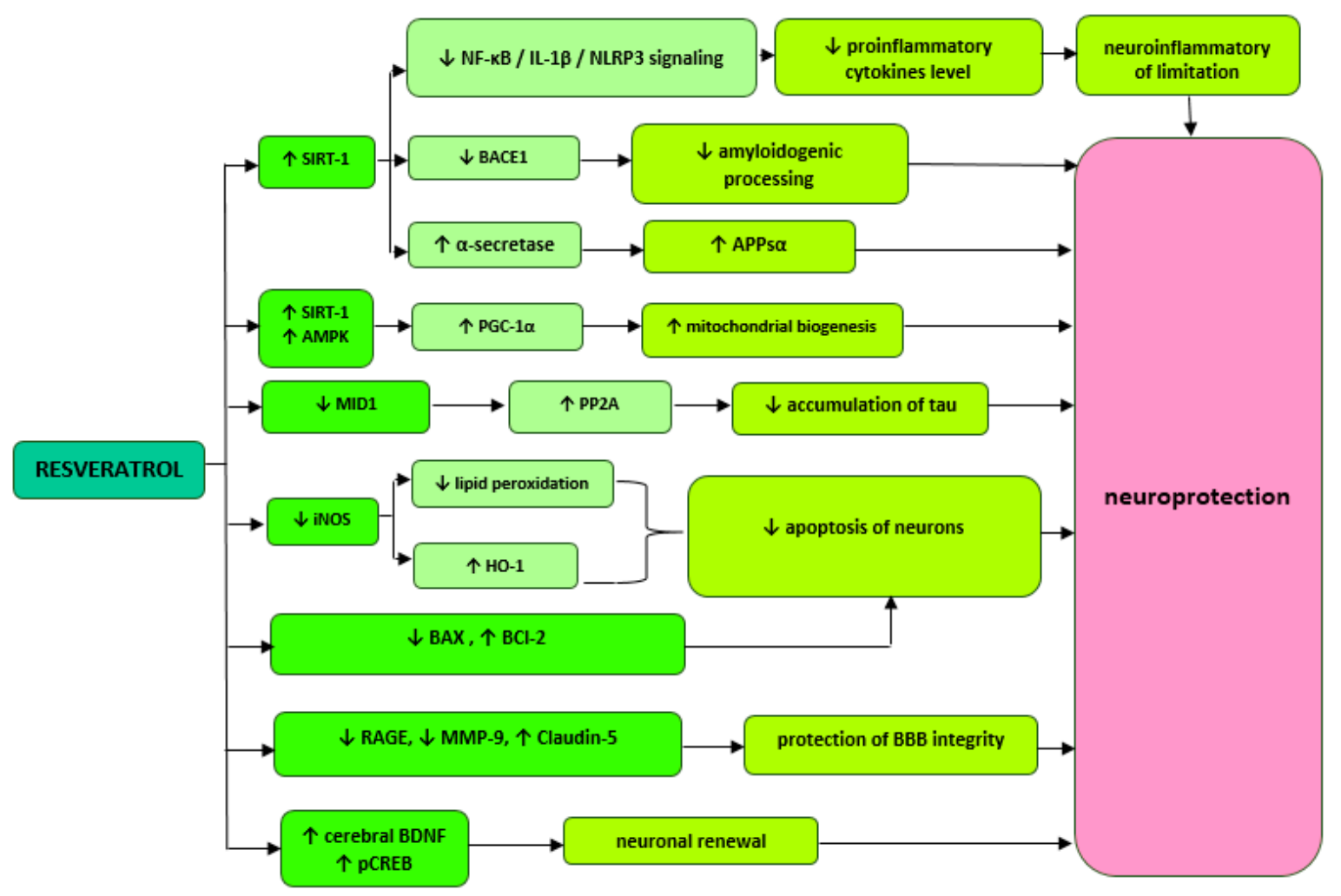

Figure 1. Proposed mechanisms of resveratrol activity. $\downarrow$-reduction, $\uparrow$-increase, SIRT1 (Sirtuin-1), NF-кB-nuclear factor kappa-light-chain-enhancer of activated B cells, BACE 1-beta-site APP cleaving enzyme 1, AMPK—AMP-activated protein kinase, PGC-1-peroxisome proliferator-activated receptor $\gamma$ coactivator- $\alpha$, MID1-ubiquitin ligase, iNOS-inducible nitric oxide synthase, HO-1-heme oxygenase-1, BCl-2-B-cell lymphoma 2, BAX-BCL2-associated X protein, PDE-phosphodiesterase 4, RAGE-glycation end products, MMP-9—metalloproteinase 9, BDNF-brain-derived neurotrophic factor.

\section{Central Nervous System Inflammation and Integrity Disorders of the Blood-Brain Barrier (BBB)}

Recently, much attention has been focused on brain endothelial cell dysfunction and microcirculation disorders present in the early stages of Alzheimer's disease [54]. It has even been hypothesized that it is vascular pathology that precedes dysfunction and degeneration of neurons [54]. A properly functioning endothelium determines the integrity of the blood-brain barrier (BBB) and maintains neurovascular balance [55]. It is known that $A \beta$ acts on the endothelium, which results in the remodeling of smooth muscle cells of small cerebral arterioles and their excessive contractility [56] leading to autoregulation disorders, a decrease in cerebral blood flow (CBF), and ultimately to cognitive impairment and dementia [57]. In fact, $A B$ 's ability to cause changes in vascular structure and destroy BBB integrity is associated with oxidative stress [58] through their association with reactive oxygen species (ROS) producing NADPH oxidase activity [57], which has significant deposits in brain blood vessels [59]. A violation of BBB integrity disrupts $A \beta$ transport contributing to the excessive accumulation of toxic $A \beta$ in the brain and further aggravating pathology [60]. Matrix metalloprotein-9 (MMP-9) and tight junction protein Claudin-5 have been shown to regulate BBB permeability and play an important role in neuropathologies such as Alzheimer's disease [61,62]. In the rat Alzheimer's disease model, resveratrol defends BBB integrity by reducing advanced glycation end products (RAGE), matrix metalloprotein-9 (MMP-9) and increasing Claudin-5 but also reduces neuroinflammation by affecting nuclear factor NF- $\mathrm{KB}$ expression [63]. It has been noticed that microglia and neuroinflammation are activated around the amyloid plaques. Resveratrol at a dose of $350 \mathrm{mg} / \mathrm{kg}$ effectively prevents the activation of microglia in the brain of APP/PS1 mouse. It is suggested that this effect is achieved through the inhibitory effects of resveratrol on the TLR4 (toll-like receptor)/NF- $\mathrm{kB} / \mathrm{STAT}$ (signal transducer and 
activator of transcription) signaling cascade [28]. Phase two of clinical tests among people with mild or moderate Alzheimer's disease confirm resveratrol's ability to modulate neuroinflammation and protect blood-brain barrier integrity [20]. Resveratrol restores BBB integrity by significantly reducing the level of matrix metalloprotein-9 (about $50 \%$ ) in cerebrospinal fluid (CSF), which can provide adequate $A \beta$ clearance and limit the inflow of inflammatory mediators into the central nervous system (CNS) [20]. Based on changes of $A \beta 40(p=0.024)$ in plasma and A $\beta 40$ in CSF $(p=0.002)$ compared to placebo, resveratrol is suggested to cross the $\mathrm{BBB}$ and affect the CNS [64]. It was observed that high-dose resveratrol treatment was paradoxically associated with greater brain volume loss [64]; on this basis, it was hypothesized that pseudoatrophy is the result of a reduction in CNS edema due to the strong anti-inflammatory effect of resveratrol [20,21].

\section{Metabolic Disorders}

The high-fat and high-glucose diets' effect on the progression of Alzheimer's disease due to metabolic dysfunction is being considered [65]. Factors of cardiovascular diseases e.g., diabetes, hypertension, and lipid disorders promote the development of neurodegenerative diseases, including Alzheimer's disease [66-69]. In turn, the Mediterranean diet plays an important role in the prevention of Alzheimer's disease [66], among others due to its protective effect on the vascular endothelium through precious polyphenols such as resveratrol and unsaturated fatty acids [70]. A relationship between high glucose levels and lower memory performance and reduced volume of the human hippocampus [71], which is particularly susceptible to carbohydrate metabolism disorders, has been shown [72]. Experimental results may indicate a beneficial effect of resveratrol treatment on improving glycemic control among patients with type 2 diabetes mellitus [73]. After three months of regular resveratrol supplementation $(250 \mathrm{mg} / \mathrm{d})$, a statistically significant reduction in $\mathrm{HbA1c}(p<0.05)$, systolic blood pressure and total cholesterol levels [73], i.e., risk factors for Alzheimer's disease [68], were observed. There is evidence that resveratrol by regulating glucose metabolism can positively affect brain functions and protect neurons [22]. It can be assumed that this effect is associated with the activation of AMP-activated protein kinase (AMPK) and SIRT1, which are known to regulate insulin sensitivity and mitochondrial biogenesis [74]. It is noted that the metabolic effects of resveratrol depend on AMPK [75]. Resveratrol by activating AMPK increases the level of $\mathrm{NAD}^{+}$by indirectly activating SIRT1 [76]. The upregulation of SIRT1 by resveratrol has been reported to prevent oxidative stress-induced endothelial cells from aging and thus may have positive effects on inhibiting atherosclerosis [77].

\section{Resveratrol Derivatives with Possible Neuroprotective Effects}

\subsection{Resveratrol Modified with Selenium Nanoparticles}

Selenium is an element necessary for the proper development and function of the brain [78]. Selenium-containing nanoparticles have been reported to be effective in treating Alzheimer's disease [79]. A $\beta$ toxicity and oxidative stress strongly correlate with neurodegenerative pathology and the cascade of many adverse events leading to Alzheimer's disease development [80]. Studies have shown that elemental selenium at nano size (Nano-Se) has high antioxidant efficacy and significantly less toxicity compared to selenomethionine (SeMet) $\left(\mathrm{LD}_{50} \mathrm{NanoSe} 92.1 \mathrm{mg} \mathrm{Se} / \mathrm{kg}\right.$ and $\mathrm{LD}_{50} \mathrm{SeMet}$ $25.6 \mathrm{mg} \mathrm{Se} / \mathrm{kg}$, respectively) [81]. Furthermore, sialic acid (SA)-modified selenium nanoparticles coated with $\mathrm{B} 6$ peptide effectively inhibit $\mathrm{A} \beta$ aggregation and promote disaggregation of fibrils into non-toxic oligomers [82]. It is suggested, that it is a promising therapeutic option in the treatment of brain diseases [82]. Similar results were obtained using stabilized epigallocatechin-3-gallate selenium nanoparticles coated with Tet-1 peptide [83]. The obtained effects are attributed to the unique properties and structure of nanomaterials; electrostatic interactions and a large surface are unfavorable conditions for the growth of peptide fibrils due to the lack of contact between monomers [5]. In the case of polyoxometalates, these properties proved to be the key to effective inhibition of polymerization at the level of $A \beta$ monomers [84]. Interestingly, the use of nanoparticles increases the stability of 
resveratrol in vivo, and thus its therapeutic potential [85]. It was noted that the reaction between $\mathrm{A} \beta$ and a redoxoactive metal ion $\left(\mathrm{Cu}^{2+}, \mathrm{Zn}^{2+}\right.$, and $\left.\mathrm{Fe}^{2+}\right)$ enhances the aggregation of $\mathrm{A} \beta$ and promotes the formation of ROS [86]. Yang et al. in their study assessed the ability of resveratrol and resveratrol modified with selenium nanoparticles to inhibit $\mathrm{Cu}^{2}$-induced aggregation and cytotoxicity of $\mathrm{A} \beta 42$. Comparing the obtained results, it can be stated that the use of selenium nanoparticles significantly improved the anti-aggregation capabilities of resveratrol. The viability of PC12 cells in the presence of resveratrol and resveratrol-functional selenium nanoparticles (RSV-SeNP) was 78\% and 93\%, respectively, relative to the control $(100 \%)$. It is believed that the more attractive ability of RSV-SeNP to inhibit the cytotoxicity induced by $\mathrm{A} \beta 42-\mathrm{Cu}^{2+}$ is due to its better antioxidant properties [87].

\subsection{Resveratrol Hybrid Compounds}

Multifunctional compounds, as multi-targeted ligands (MTDL), have been reported to appear to be a promising therapeutic option in neurodegenerative diseases, including Alzheimer's disease [88]. Many hybrid compounds with different pharmacophores have been developed (Table 2) and their in vitro biological activity has been evaluated.

Table 2. Resveratrol hybrid compounds in studies in vitro.

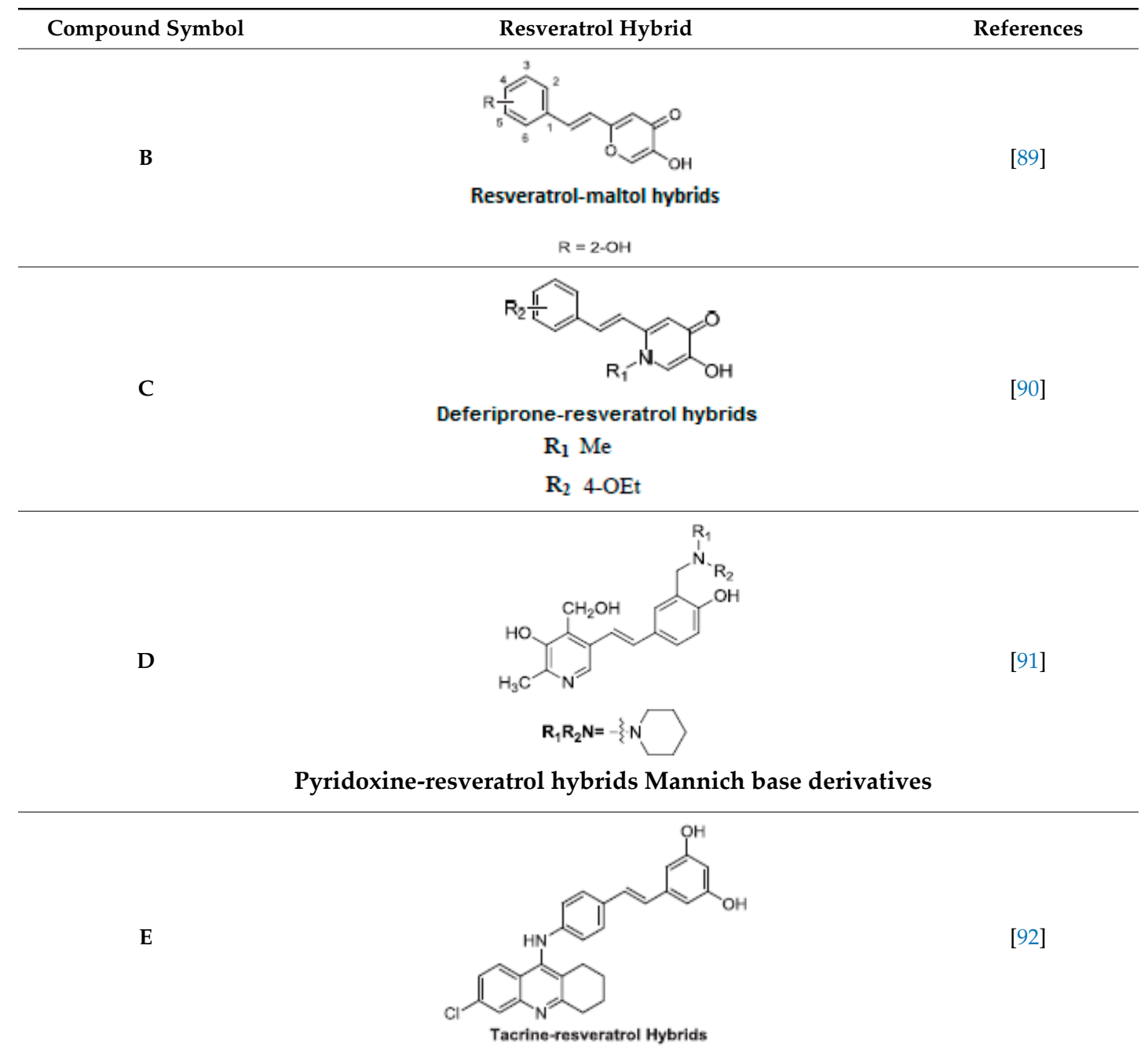

ThT—-thioflavin-T based fluorometric assay, ORAC—oxygen radical absorbance capacity.

It is known that the deposition of $\mathrm{A} \beta$ in the brain stimulates astrocytes and microglia leading to neurosurgitis and neuronal apoptosis [93,94]. As previously mentioned, $\mathrm{Cu}^{2+}, \mathrm{Zn}^{2+}$, and $\mathrm{Fe}^{2+}$ dyshomeostasis accelerates $A \beta$ aggregation and causes oxidative stress [95] associated with neuronal 
degeneration [89]. Therefore, a strategy focused on these molecular Alzheimer's disease goals may be appropriate. Cheng et al. obtained by replacing the resveratrol benzene ring with a metal-maltol chelating group, a series of hybrids and assessed their ability to inhibit aggregation of $A \beta 42$, antioxidant and metal-binding with positive effects. Compound $B$ inhibited the aggregation of $\mathrm{A} \beta 42$ at $\mathrm{IC}_{50}=8.29 \mu \mathrm{M}\left(\mathrm{IC}_{50}\right.$ resveratrol $\left.=11.89 \mu \mathrm{M}\right)$ and promoted disaggregation of $\mathrm{A} \beta$ induced by $\mathrm{Fe}^{3+}$ ions ( $p<0.01$ relative to control) [96]. Other researchers, on the other hand, used deferiprone, an oral iron-chelating drug, among patients with thalassemia [97] to synthesize hybrids with resveratrol [90]. Hybrid $\mathrm{C}$ was distinguished by a high inhibition of $\mathrm{A} \beta 42$ aggregation induced by $\mathrm{Cu}^{2+} / \mathrm{Fe}^{3+}$ ions (decrease in ThT fluorescence to $57 \%$ and $64 \%, p<0.01$, for resveratrol $86 \%$ with copper and $87 \%$ with iron, respectively) [90]. What's more, compound D hybrid pyridoxine and resveratrol, a Mannich base derivative, in addition to good antioxidant properties (ORAC: 2.56) had a dual inhibitor function; it inhibited both acetylcholinesterase (AchE) $\left(\mathrm{IC}_{50}=2.11 \mu \mathrm{M}\right)$ and monoamine oxidase $\mathrm{B}$ (MAO-B) $\left(\mathrm{IC}_{50}=12.4 \mu \mathrm{M}\right)$ [91]. It has been noted that MAO-B may be responsible for the development of Alzheimer's disease [98], because one of the products of reactions catalyzed by MAO-B is hydrogen peroxide, which can become a source of reactive oxygen species [99]. Jeřábek et al. combined resveratrol with the cholinesterase inhibitor tacrine (compound E). Good hAChE inhibitory ability, anti-A $\beta 42$ aggregation and protective effects on primary cultures of lipopolysaccharide (LPS)-treated astrocytes were obtained. Despite the many advantages of this combination, clinical use may be limited due to hepatotoxic potential [92].

\subsection{Melinjo and Gnetin C Extracts}

Gnetin $C$ is a natural stilben, resveratrol dimer, isolated among others from seeds of the Melinjo plant (Gnetum gnemon L.) [100] and XinJiang vine stems [101]. Melinjo seeds are an essential ingredient in Indonesian food and contain a mixture of stilbenoids (Table 3) with excellent free radical scavenging properties as well as antimicrobial activity against enterobacteria and food microorganisms [102].

Table 3. Resveratrol derivatives in MSE [103] and chemical structure of resveratrol dimer derivatives [102].

\begin{tabular}{|c|c|}
\hline Resveratrol Derivatives in MSE & Chemical Structure of Resveratrol Dimer Derivatives \\
\hline $\begin{array}{l}\text { Trans-resveratrol } \\
\text { Trans-piceid } \\
\text { Isorhapontigenin }\end{array}$ & но' \\
\hline & resveratrol \\
\hline $\begin{array}{l}\text { Resveratrol Dimers: } \\
\text { GC: Gnetin C } \\
\text { GL: Gnetin L } \\
\text { GMA: Gnemonoside A } \\
\text { GMC: Gnemonoside C } \\
\text { GMD: Gnemonoside D }\end{array}$ & $\begin{array}{l}\mathrm{R}_{1} \\
\text { GC: } \mathrm{R}_{1}=\mathrm{R}_{3}=\mathrm{R}_{4}=\mathrm{H}, \mathrm{R}_{2}=\mathrm{OH} \\
\text { GL: } \mathrm{R}_{1}=\mathrm{OCH}_{3}, \mathrm{R}_{2}=\mathrm{R}_{4}=\mathrm{H}, \mathrm{R}_{3}=\mathrm{OH} \\
\text { GMA: } \mathrm{R}_{1}=\mathrm{R}_{3}=\mathrm{H}, \mathrm{R}_{2}=\mathrm{OGlc}, \mathrm{R}_{4}=\mathrm{Glc} \\
\text { GMC: } \mathrm{R}_{1}=\mathrm{R}_{3}=\mathrm{R}_{4}=\mathrm{H}, \mathrm{R}_{2}=\mathrm{OGlc} \\
\text { GMD: } \mathrm{R}_{1}=\mathrm{R}_{3}=\mathrm{H}, \mathrm{R}_{2}=\mathrm{OH}, \mathrm{R}_{4}=\text { Glc }\end{array}$ \\
\hline
\end{tabular}

In addition, vasoprotective properties [104] and anti-tumor melinjo [105] extracts have been reported. Kunimasa et al. showed in their studies that Gnetin $C$ can inhibit proliferation $(p<0.05)$ and tube formation $\left(\mathrm{IC}_{50}=2.6 \mu \mathrm{M}\right.$ ) of human umbilical vein endothelial cells (HUVEC) much more strongly than resveratrol $\left(\mathrm{IC}_{50}=28.9 \mu \mathrm{M}\right)$. It has been observed that the antiproliferative properties of Gnetin $\mathrm{C}$ may be due to its ability to inactivate extracellular signal-regulated kinase ERK1/2 induced by vascular 
endothelial growth factor and basic fibroblast growth factor (VEGF-bFGF) [106]. RAF-MEK1/2-ERK1/2 signaling disorders have been reported to promote tumor development, and ERK1/2 inhibitors are an effective weapon in the fight against this disease [107]. In their work, Syota et al. assessed the effect of treatment with $20 \mu \mathrm{M}$ Gnetin $C, \varepsilon$-viniferin, and resveratrol on the production of $A \beta 42$ monomers in human neuroblastoma cells SH-SY5Y. Gnetin C showed the best effectiveness; it reduced the production of $\mathrm{A} \beta 42$ monomers by as much as $63 \%$, while $\varepsilon$-viniferin and resveratrol by $34 \%$ and $33 \%$, respectively. This effect is attributed to the ability to inhibit BACE-1 expression $(p<0.05)$ and induction of expression of MMP-14 (matrix metalloproteinase-14), an A $\beta$ degrading enzyme $(p<0.05)$ [108]. Ikuta et al. in their studies in mice compared the use of a high-fat diet with a combination of this diet and $2.0 \%$ MSE $^{*}$. After eight weeks, the results in both groups were evaluated. In the MSE group, a significant reduction in weight gain $(p<0.001)$, blood insulin $(p<0.01)$ and HOMA-IR index $(p<0.05)$ was achieved, however, without affecting the corresponding lipoprotein fractions (Table 4). Furthermore, it was noted that supplementation with $0.2 \%$ melinjo extract containing Gnetin $C$ in mice fed high-fat diets reduced the risk of death by $25 \%(p=0.036)$ [109]. Recent studies show that high doses of MSE $(5000 \mathrm{mg})$ in powder form are safe for humans and are not associated with serious adverse events [103]. In double-blind, randomized controlled study Konno et al. studied the beneficial effects of using $750 \mathrm{mg}$ of MSE powder by healthy Japanese men. After eight weeks of treatment, a statistically significant decrease in uric acid level $(p<0.05)$ and an increase in serum HDL cholesterol $(p<0.05)$ were obtained, without affecting LDL cholesterol. Interestingly, it has been shown that the ability of MSE and Gnetin $C$ to reduce uric acid may be due to the inhibition of AT1 activity, not xanthine oxidase. It is suggested that by agonistic action on peroxisome proliferator-activated receptor (PPAR $\alpha$ and PPAR $\gamma$ ), MSE leads to an increase in HDL levels [104]. The safety of pure Gnetin C (150 mg/day), its better bioavailability than resveratrol and the ability to lower uric acid in serum was confirmed in a randomized phase one clinical test. It is worth noting that two-week supplementation of pure Gnetin $\mathrm{C}$ by healthy people was associated with a significant reduction of HDL-C $(p=0.025)$, LDL-C $(p=0.011)$ and adiponectin $(p=0.000087)$ in serum compared to placebo, which is in contradiction to previous studies and appears to promote the progression of atherosclerosis [110]. Therefore, further research is needed to determine the effect of Gnetin C on the metabolic profile in humans. Other researchers evaluated the effect of using MSE in healthy individuals on plasma oxidative stress parameters. After 28 days of administration of MSE containing $262 \mathrm{mg}$ Gnetin C and $5.8 \mathrm{mg}$ resveratrol per day, the plasma antioxidant capacity was 2.5 times higher than at the beginning of the study $(p=0.01)$. In plasma samples taken after two weeks of MES ingestion, the average concentration of Gnetin C $(0.344 \pm 0.205 \mu \mathrm{g} / \mathrm{mL})$ was significantly higher than that of resveratrol $((0.0612 \pm 0.0535 \mu \mathrm{g} / \mathrm{mL})$. In addition, Espinoza et al. examined the expression of proinflammatory cytokines from peripheral blood mononuclear cells (PBMCs) cultured with or without MES in vitro. It has been observed that MSE inhibits the secretion of interferon- $\gamma($ IFN- $\gamma$ ) and tumor necrosis factor $\alpha$ (TNF- $\alpha$ ) from PBMCs activated with phytohemagglutinin A (PHA) in a concentration-dependent manner. The results obtained may indicate good in vivo antioxidant and in-vitro anti-inflammatory properties [111].

Nakagami et al. observed that the plasma concentration of Gnetin $C$ on the 14th day of supplementation ( $150 \mathrm{mg} /$ day) was in the range of 601 to $2490 \mathrm{ng} / \mathrm{mL}$, and 14 days after the last dose in the range of $27-98 \mathrm{ng} / \mathrm{mL}$, and its concentration monoglucuronide metabolite in the range $86-862 \mathrm{ng} / \mathrm{mL}$ [110]. However, in the case of resveratrol Walle et al. reported that it undergoes intensive and rapid metabolism in the human body, which means that its bioavailability is very low, and only a trace amount of unchanged resveratrol $(<5 \mathrm{ng} / \mathrm{mL})$ and quite high concentration of the metabolites $491+/-90 \mathrm{ng} / \mathrm{mL}$ (about $2 \mu \mathrm{M}$ ) remain in plasma after oral administration of $25 \mathrm{mg}$. Maximum total plasma radioactivity was $491+/-90 \mathrm{ng} / \mathrm{mL}$ and was reached $1 \mathrm{~h}$ after oral administration. Interestingly, resveratrol absorption from the gastrointestinal tract is large and amounts to at least $70 \%$ [112]. Other researchers, in turn, administered $50 \mathrm{mg}$ of resveratrol to rats to assess its tissue distribution. After $2 \mathrm{~h}$, plasma resveratrol concentration accounted for $1.7 \%$ of the total dose administered, and after $18 \mathrm{~h}$ only $0.5 \%$. The highest resveratrol concentration $2 \mathrm{~h}$ after administration was found in the liver 
$(1 \%)$ and kidneys $(0.6 \%)$, while in the brain less than $0.1 \%$ (about $0.03 \%$ ) of the dose administered was found, with resveratrol concentration in brain tissue showing a slower decrease compared to liver and kidneys [113].

Table 4. MSE and Gnetin C in vivo studies.

\begin{tabular}{|c|c|c|c|c|}
\hline Subject of Study & Dose (p.o) & Duration of Treatment & Effect & Reference \\
\hline Healthy man & $\begin{array}{c}750 \mathrm{mg} / \text { day of MSE powder } \\
(>20 \% \text { resveratrol } \\
\text { derivatives, including only } \\
0.75 \mathrm{mg} / \text { day of resveratrol) }\end{array}$ & 8 weeks & $\begin{array}{c}\uparrow \text { HDL } \\
\downarrow \text { uric acid in serum }\end{array}$ & [104] \\
\hline $\begin{array}{l}\text { Diet-induced } \\
\text { obesity mouse } \\
\text { model }\end{array}$ & $\begin{array}{c}\text { High-fat diet (HFD) + } \\
2.0 \% \text { MSE }\end{array}$ & 8 weeks & $\begin{array}{c}\downarrow \text { weight gain } \\
\downarrow \text { insulin in blood } \\
\downarrow \text { HOMA-IR }\end{array}$ & [109] \\
\hline Healthy person & $150 \mathrm{mg} /$ day of Gnetin C & 2 weeks & $\begin{array}{c}\downarrow \text { uric acid } \\
\downarrow \text { HDL } \\
\downarrow \text { LDL } \\
\downarrow \text { adiponectin } \\
\text { in serum } \\
\text { well tolerated }\end{array}$ & [110] \\
\hline Healthy person & $\begin{array}{c}320 \mathrm{mg} / \text { day of MSE } \\
(262 \mathrm{mg}(2.57 \%) \text { of Gnetin C } \\
5.8 \mathrm{mg}(0.09 \%) \text { of } \\
\text { trans-resveratrol })\end{array}$ & 28 days & $\begin{array}{c}\uparrow \text { serum antioxidant } \\
\text { activity } \\
\text { well tolerated }\end{array}$ & [111] \\
\hline
\end{tabular}

MSE-Melinjo seed extracts (resveratrol dimers: gnemonoside A, C, D; gnetin C; trans-resveratrol; other resveratrol derivatives), HDL—high density lipoprotein, LDL—low density lipoprotein, HOMA-IR—homeostasis model assessment of insulin resistance.

\section{Conclusions}

The information presented in this article allows resveratrol and its derivatives to be considered as potential neuroprotective agents capable of affecting many pathological cascade targets leading to the development of Alzheimer's disease. Inhibition of the aggregation of toxic $A \beta$ appears to play a key role in reducing AD-related neurodegeneration. Free radical scavenging and anti-inflammatory properties may be helpful in preventing cerebrovascular endothelial dysfunction and maintaining normal blood-brain barrier integrity. When designing new drugs against Alzheimer's disease, it is worth considering the use of modifications based on selenium nanoparticles and hybrid resveratrol derivatives with its beneficial effects. The modified molecules showed better antioxidant and anti-aggregation activity in vitro. If their potential effect on the protection of neuronal cells is proven in vivo research, they may find use in the treatment of brain diseases. The fact that resveratrol is extensively metabolized in the body and its bioavailability is low, significantly limits its clinical use. Gnetin C, a natural stillben, resveratrol dimer contained in the seeds of Gnetum gnemon L. has better pharmacokinetic properties. If the ability of pure Gnetin $C$ to prevent cardiovascular diseases associated with metabolic syndrome was proven, this compound could prove useful in reducing the burden of certain neurodegenerative diseases, including Alzheimer's disease. Additional studies are necessary to verify the effect of Gnetin $\mathrm{C}$ on the metabolic profile in humans. However, for any incurable disease medicine to be effective, it is necessary to know and understand its exact mechanism, which in the case of Alzheimer's disease is still unclear.

Funding: This research received no external funding.

Conflicts of Interest: The authors declare no conflict of interest.

\section{References}

1. Alzheimer's Association. Alzheimer's disease facts and figures. Alzheimers Dement. 2016, 12, 459-509.

2. Cummings, J.L.; Morstorf, T.; Zhong, K. Alzheimer's disease drug-development pipeline: Few candidates, frequent failures. Alzheimer's Res. Ther. 2014, 6, 37. [CrossRef] [PubMed] 
3. Chu, L.W. Alzheimer's disease: Early diagnosis and treatment. Hong Kong Med. J. 2012, 18, $228-237$. [PubMed]

4. Anand, R.; Gill, K.D.; Mahdi, A.A. Therapeutics of Alzheimer's disease: Past, present and future. Neuropharmacology 2014, 76, 27-50. [CrossRef] [PubMed]

5. Castellani, R.J.; Rolston, R.K.; Smith, M.A. Alzheimer Disease. Dis. Mon. 2010, 56, 484-546. [CrossRef]

6. Agis-Torres, A.; Sölhuber, M.; Fernandez, M.; Sanchez-Montero, J.M. Multi-Target-Directed Ligands and other Therapeutic Strategies in the search of a Real Solution for Alzheimer's Disease. Curr. Neuropharmacol. 2014, 12, 2-36. [CrossRef] [PubMed]

7. Racine, A.M.; Merluzzi, A.P.; Adluru, N.; Norton, D.; Koscik, R.L.; Clark, L.R.; Berman, S.E.; Nicholas, C.R. Association of longitudinal white matter degeneration and cerebrospinal fluid biomarkers of neurodegeneration, inflammation and Alzheimer's disease in late-middle-aged adults. Brain Imaging Behav. 2019, 13, 41-52. [CrossRef]

8. Arshavsky, Y.I. Alzheimer disease and cellular mechanisms of memory storage. J. Neuropathol. Exp. Neurol. 2014, 73, 192-205. [CrossRef]

9. Hamley, I.W. The amyloid beta peptide: A chemist's perspective. Role in Alzheimer's and fibrillization. Chem. Rev. 2012, 112, 5147-5192. [CrossRef]

10. Forloni, G.; Balducci, C. Alzheimer's Disease, Oligomers, and Inflammation. J. Alzheimers Dis. 2018, 62, 1261-1276. [CrossRef]

11. Lasagna-Reeves, C.A.; Castillo-Carranza, D.L.; Guerrero-Muoz, M.J.; Jackson, G.R.; Kayed, R. Preparation and characterization of neurotoxic tau oligomers. Biochemistry 2010, 49, 10039-10041. [CrossRef] [PubMed]

12. Gadad, B.S.; Britton, G.B.; Rao, K.S. Targeting oligomers in neurodegenerative disorders: Lessons from $\alpha$-synuclein, tau, and amyloid- $\beta$ peptide. J. Alzheimers Dis. 2011, 24, 223-232. [CrossRef] [PubMed]

13. Fá, M.; Puzzo, D.; Piacentini, R. Extracellular Tau Oligomers Produce an Immediate Impairment of LTP and Memory. Sci. Rep. 2016, 6, 19393. [CrossRef] [PubMed]

14. De Strooper, B. Proteases and proteolysis in Alzheimer disease: A multifactorial view on the disease process. Physiol. Rev. 2010, 90, 465-494. [CrossRef]

15. Schelle, J.; Wegenast-Braun, B.M.; Fritschi, S.K.; Kaeser, S.A.; Jährling, N.; Eicke, D.; Skodras, A.; Beschorner, N.; Obermueller, U.; Häsler, L.M.; et al. Early A $\beta$ reduction prevents progression of cerebral amyloid angiopathy. Ann. Neurol. 2019, 86, 561-571. [CrossRef]

16. Wiciński, M.; Socha, M.; Walczak, M.; Wódkiewicz, E.; Malinowski, B.; Rewerski, S.; Górski, K.; Pawlak-Osińska, K. Beneficial Effects of Resveratrol Administration-Focus on Potential Biochemical Mechanisms in Cardiovascular Conditions. Nutrients 2018, 10, 1813. [CrossRef]

17. Sharma, M.; Gupta, Y.K. Chronic treatment with trans resveratrol prevents intracerebroventricular streptozotocin induced cognitive impairment and oxidative stress in rats. Life Sci. 2002, 71, 2489-2498. [CrossRef]

18. Huang, T.C.; Lu, K.T.; Wo, Y.Y.; Wu, Y.J.; Yang, Y.L. Resveratrol Protects Rats from A $\beta$-induced Neurotoxicity by the Reduction of iNOS Expression and Lipid Peroxidation. PLoS ONE 2011, 6, e29102. [CrossRef]

19. Wang, G.; Chen, L.; Pan, X.; Chen, J.; Wang, L.; Wang, W.; Cheng, R.; Wu, F.; Feng, X.; Yu, Y.; et al. The effect of resveratrol on beta amyloid-induced memory impairment involves inhibition of phosphodiesterase-4 related signalling. Oncotarget 2016, 7, 17380-17392.

20. Moussa, C.; Hebron, M.; Huang, X.; Ahn, J.; Rissman, R.A.; Aisen, P.S.; Turner, R.S. Resveratrol regulates neuroinflammation and induces adaptive immunity in Alzheimer's disease. J. Neuroinflamm. 2017, 14, 1. [CrossRef]

21. Sawda, C.; Moussa, C.; Turner, R.S. Resveratrol for Alzheimer's disease. Ann. N. Y. Acad. Sci. 2017, 1403, 142-149. [CrossRef] [PubMed]

22. Witte, A.V.; Kerti, L.; Margulies, D.S.; Flöel, A. Effects of resveratrol on memory performance, hippocampal functional connectivity, and glucose metabolism in healthy older adults. J. Neurosci. 2014, 34, 7862-7870. [CrossRef] [PubMed]

23. Zhu, C.W.; Grossman, H.; Neugroschl, J.; Parker, S.; Burden, A.; Luo, X.; Sano, M. A randomized, double-blind, placebo-controlled trial of resveratrol with glucose and malate (RGM) to slow the progression of Alzheimer's disease: A pilot study. Alzheimers Dement. (N. Y.) 2018, 4, 609-616. [CrossRef] [PubMed] 
24. Wiciński, M.; Malinowski, B.; Weclewicz, M.M.; Grześk, E.; Grześk, G. Resveratrol increases serum BDNF concentrations and reduces vascular smooth muscle cells contractility via a NOS-3-independent mechanism. BioMed Res. Int. 2017, 2017, 9202954. [CrossRef] [PubMed]

25. Porquet, D.; Griñán-Ferré, C.; Ferrer, I.; Camins, A.; Sanfeliu, C.; Del Valle, J.; Pallàs, M. Neuroprotective role of trans-resveratrol in a murine model of familial Alzheimer's disease. J. Alzheimers Dis. 2014, 42, 1209-1220. [CrossRef]

26. Qi, Y.; Shang, L.; Liao, Z.; Su, H.; Jing, H.; Wu, B.; Bi, K.; Jia, Y. Intracerebroventricular injection of resveratrol ameliorated $A \beta$-induced learning and cognitive decline in mice. Metab. Brain Dis. 2019, 34, 257-266. [CrossRef]

27. Corpas, R.; Griñán-Ferré, C.; Rodríguez-Farré, E.; Pallàs, M.; Sanfeliu, C. Resveratrol Induces Brain Resilience Against Alzheimer Neurodegeneration Through Proteostasis Enhancement. Mol. Neurobiol. 2019, 56, 1502-1516. [CrossRef]

28. Capiralla, H.; Vingtdeux, V.; Zhao, H.; Sankowski, R.; Al-Abed, Y.; Davies, P.; Marambaud, P. Resveratrol mitigates lipopolysaccharide- and A $\beta$-mediated microglial inflammation by inhibiting the TLR4/NF-KAPPAB/STAT signaling cascade. J. Neurochem. 2012, 120, 461-472. [CrossRef]

29. Kim, D.; Nguyen, M.D.; Dobbin, M.M.; Fischer, A.; Sananbenesi, F.; Rodgers, J.T.; Delalle, I.; Baur, J.A.; Sui, G.; Armour, S.M.; et al. SIRT1 deacetylase protects against neurodegeneration in models for Alzheimer's disease and amyotrophic lateral sclerosis. EMBO J. 2007, 26, 3169-3179. [CrossRef]

30. Choi, C.W.; Choi, Y.H.; Cha, M.R.; Kim, Y.S.; Yon, G.H.; Hong, K.S.; Park, W.K.; Kim, Y.H.; Ryu, S.Y. In vitro BACE-1 inhibitory activity of resveratrol oligomers from the seed extract of Paeonia lactiflora. Planta Med. 2011, 77, 374-376. [CrossRef]

31. Marambaud, P.; Zhao, H.; Davies, P. Resveratrol promotes clearance of Alzheimer's disease amyloid- $\beta$ peptides. J. Biol. Chem. 2005, 280, 37377-37382. [CrossRef] [PubMed]

32. Feng, Y.; Wang, X.P.; Yang, S.G.; Wang, Y.J.; Zhang, X.; Du, X.T.; Sun, X.X.; Zhao, M.; Huang, L.; $\mathrm{Liu}$, R.T. Resveratrol inhibits beta-amyloid oligomeric cytotoxicity but does not prevent oligomer formation. Neurotoxicology 2009, 30, 986-995. [CrossRef] [PubMed]

33. Li, S.; Selkoe, D.J. A mechanistic hypothesis for the impairment of synaptic plasticity by soluble Ab oligomers from Alzheimer brain. J. Neurochem. 2020. [CrossRef]

34. Sengupta, U.; Nilson, A.N.; Kayed, R. The Role of Amyloid- $\beta$ Oligomers in Toxicity, Propagation, and Immunotherapy. EBioMedicine 2016, 6, 42-49. [CrossRef] [PubMed]

35. Endres, K.; Fahrenholz, F. Regulation of $\alpha$-secretase ADAM10 expression and activity. Exp. Brain Res. 2012, 217, 343-352. [CrossRef]

36. Lammich, S.; Buell, D.; Zilow, S.; Ludwig, A.K.; Nuscher, B.; Lichtenthaler, S.F.; Prinzen, C.; Fahrenholz, F.; Haass, C. Expression of the anti-amyloidogenic secretase ADAM10 is suppressed by its $5^{\prime}$-untranslated region. J. Biol. Chem. 2010, 285, 15753-15760. [CrossRef]

37. Abdelmohsen, K.; Pullmann, R., Jr.; Lal, A.; Kim, H.H.; Galban, S.; Yang, X.; Blethrow, J.D.; Walker, M.; Shubert, J.; Gillespie, D.A. Phosphorylation of HuR by Chk2 regulates SIRT1 expression. Mol. Cell 2007, 25, 543-557. [CrossRef]

38. Howitz, K.T.; Bitterman, K.J.; Cohen, H.Y.; Lamming, D.W.; Lavu, S.; Wood, J.G.; Zipkin, R.E.; Chung, P.; Kisielewski, A.; Zhang, L.L. Small molecule activators of sirtuins extend Saccharomyces cerevisiae lifespan. Nature 2003, 425, 191-196. [CrossRef]

39. Donmez, G.; Outeiro, T.F. SIRT1 and SIRT2, emerging targets in neurodegeneration. EMBO Mol. Med. 2013, 5, 344-352. [CrossRef]

40. Cacabelos, R.; Carril, J.C.; Cacabelos, N.; Kazantsev, A.G.; Vostrov, A.V.; Corzo, L.; Cacabelos, P.; Goldgaber, D. Sirtuins in Alzheimer's Disease: SIRT2-Related GenoPhenotypes and Implications for PharmacoEpiGenetics. Int. J. Mol. Sci. 2019, 20, 1249. [CrossRef]

41. Borra, M.T.; Smith, B.C.; Denu, J.M. Mechanism of human SIRT1 activation by resveratrol. J. Biol. Chem. 2005, 280, 17187-17195. [CrossRef] [PubMed]

42. Wiciński, M.; Malinowski, B.; Węclewicz, M.M.; Grześk, E.; Grześk, G. Anti-atherogenic properties of resveratrol: 4-week resveratrol administration associated with serum concentrations of SIRT1, adiponectin, S100A8/A9 and VSMCs contractility in a rat model. Exp. Ther. Med. 2017, 13, 2071-2078. [CrossRef] [PubMed] 
43. Zhao, H.; Wang, Q.; Cheng, X.; Li, X.; Li, N.; Liu, T.; Li, J.; Yang, Q.; Dong, R.; Zhang, Y.; et al. Inhibitive effect of resveratrol on the inflammation in cultured astrocytes and microglia induced by $\mathrm{A} \beta 1-42$. Neuroscience 2018, 379, 390-404. [CrossRef] [PubMed]

44. Kao, C.L.; Chen, L.K.; Chang, Y.L.; Yung, M.C.; Hsu, C.C.; Chen, Y.C.; Lo, W.L.; Chen, S.J.; Ku, H.H.; Hwang, S.J. Resveratrol protects human endothelium from $\mathrm{H}(2) \mathrm{O}(2)$-induced oxidative stress and senescence via SirT1 activation. J. Atheroscler. Thromb. 2010, 17, 970-979. [CrossRef]

45. Julien, C.; Tremblay, C.; Emond, V.; Lebbadi, M.; Salem, N., Jr.; Bennett, D.A.; Calon, F. Sirtuin 1 reduction parallels the accumulation of tau in Alzheimer disease. J. Neuropathol. Exp. Neurol. 2009, 68, 48-58. [CrossRef]

46. Bodea, LG.; Eckert, A.; Ittner, LM.; Piguet, O.; Götz, J. Tau physiology and pathomechanisms in frontotemporal lobar degeneration. J. Neurochem. 2016, 138, 71-94. [CrossRef]

47. Min, S.W.; Cho, S.H.; Zhou, Y.; Schroeder, S.; Haroutunian, V.; Seeley, W.W.; Huang, E.J.; Shen, Y.; Masliah, E.; Mukherjee, C.; et al. Acetylation of tau inhibits its degradation and contributes to tauopathy. Neuron 2010, 67, 953-966. [CrossRef]

48. Schweiger, S.; Matthes, F.; Posey, K.; Kickstein, E.; Weber, S.; Hettich, M.M.; Pfurtscheller, S.; Ehninger, D.; Schneider, R.; Krauß, S. Resveratrol induces dephosphorylation of Tau by interfering with the MID1-PP2A complex. Sci. Rep. 2017, 7, 13753. [CrossRef]

49. Singh, A.; Kukreti, R.; Saso, L.; Kukreti, S. Oxidative Stress: A Key Modulator in Neurodegenerative Diseases. Molecules 2019, 24, 1583. [CrossRef]

50. Peña-Bautista, C.; Baque ro, M.; Vento, M.; Cháfer-Pericás, C. Free radicals in Alzheimer's disease: Lipid peroxidation biomarkers. Clin. Chim. Acta. 2019, 491, 85-90. [CrossRef]

51. Tamagno, E.; Guglielmotto, M.; Aragno, M.; Borghi, R.; Autelli, R.; Giliberto, L.; Muraca, G.; Danni, O.; Zhu, X.; Smith, M.A.; et al. Oxidative stress activates a positive feedback between the gamma- and beta-secretase cleavages of the beta-amyloid precursor protein. J. Neurochem. 2008, 104, 683-695. [PubMed]

52. Pall, M.L. Nitric oxide synthase partial uncoupling as a key switching mechanism for the NO/ONOO-cycle. Med. Hypotheses 2007, 69, 821-825. [CrossRef] [PubMed]

53. Park, L.; Wang, G.; Moore, J.; Girouard, H.; Zhou, P.; Anrather, J.; Iadecola, C. The key role of transient receptor potential melastatin-2 channels in amyloid-beta-induced neurovascular dysfunction. Nat. Commun. 2014, 5, 5318. [CrossRef] [PubMed]

54. Garwood, C.J.; Simpson, J.E.; Al Mashhadi, S.; Axe, C.; Wilson, S.; Heath, P.R.; Shaw, P.J.; Matthews, F.E.; Brayne, C.; Ince, P.G.; et al. DNA damage response and senescence in endothelial cells of human cerebral cortex and relation to Alzheimer's neuropathology progression: A population-based study in the Medical Research Council Cognitive Function and Ageing Study (MRC-CFAS) cohort. Neuropathol. Appl. Neurobiol. 2014, 40, 802-814. [CrossRef] [PubMed]

55. Koizumi, K.; Wang, G.; Park, L. Endothelial Dysfunction and Amyloid- $\beta$-Induced Neurovascular Alterations. Cell Mol. Neurobiol. 2016, 36, 155-165. [CrossRef]

56. Chow, N.; Bell, R.D.; Deane, R.; Streb, J.W.; Chen, J.; Brooks, A.; Van Nostrand, W.; Miano, J.M.; Zlokovic, B.V. Serum response factor and myocardin mediate arterial hypercontractility and cerebral blood flow dysregulation in Alzheimer's phenotype. Proc. Natl. Acad. Sci. USA 2007, 104, 823-828. [CrossRef]

57. Park, L.; Anrather, J.; Zhou, P.; Frys, K.; Pitstick, R.; Younkin, S.; Carlson, G.A.; Iadecola, C. NADPH-oxidase-derived reactive oxygen species mediate the cerebrovascular dysfunction induced by the amyloid beta peptide. J. Neurosci. 2005, 25, 1769-1777. [CrossRef]

58. Hamel, E.; Nicolakakis, N.; Aboulkassim, T.; Ongali, B.; Tong, XK. Oxidative stress and cerebrovascular dysfunction in mouse models of Alzheimer's disease. Exp Physiol. 2008, 93, 116-120. [CrossRef]

59. Drummond, G.R.; Selemidis, S.; Griendling, K.K.; Sobey, C.G. Combating oxidative stress in vascular disease: NADPH oxidases as therapeutic targets. Nat. Rev. Drug Discov. 2011, 10, 453-471. [CrossRef]

60. Shackleton, B.; Crawford, F.; Bachmeier, C. Inhibition of ADAM10 promotes the clearance of A $\beta$ across the BBB by reducing LRP1 ectodomain shedding. Fluids Barriers CNS 2016, 13, 14. [CrossRef]

61. Ashok, A.; Rai, N.K.; Raza, W.; Pandey, R.; Bandyopadhyay, S. Chronic cerebral hypoperfusion-induced impairment of $\mathrm{A} \beta$ clearance requires HB-EGF-dependent sequential activation of HIF1 $\alpha$ and MMP9. Neurobiol. Dis. 2016, 95, 179-193. [CrossRef] [PubMed]

62. Greene, C.; Hanley, N.; Campbell, M. Claudin-5, gatekeeper of neurological function. Fluids Barriers CNS 2019, 16, 3. [CrossRef] [PubMed] 
63. Zhao, H.F.; Li, N.; Wang, Q.; Cheng, X.J.; Li, X.M.; Liu, T.T. Resveratrol decreases the insoluble A $\beta 1-42$ level in hippocampus and protects the integrity of the blood-brain barrier in AD rats. Neuroscience 2015, 310, 641-649. [CrossRef] [PubMed]

64. Turner, R.S.; Thomas, R.G.; Craft, S.; van Dyck, C.H.; Mintzer, J.; Reynolds, B.A.; Brewer, J.B.; Rissman, R.A.; Raman, R.; Aisen, P.S. A randomized, double-blind, placebo-controlled trial of resveratrol for Alzheimer disease. Neurology 2015, 85, 1383-1391. [CrossRef] [PubMed]

65. Brasnyó, P.; Molnár, G.A.; Mohás, M.; Markó, L.; Laczy, B.; Cseh, J.; Mikolás, E.; Szijártó, I.S.; Mérei, Á.; Halmai, R.; et al. Resveratrol improves insulin sensitivity, reduces oxidative stress and activates the Akt pathway in type 2 diabetic patients. Br. J. Nutr. 2011, 106, 383-389. [CrossRef] [PubMed]

66. Hersi, M.; Irvine, B.; Gupta, P.; Gomes, J.; Birkett, N.; Krewski, D. Risk factors associated with the onset and progression of Alzheimer's disease: A systematic review of the evidence. Neurotoxicology 2017, 61, 143-187. [CrossRef] [PubMed]

67. Daviglus, M.L.; Plassman, B.L.; Pirzada, A.; Bell, C.C.; Bowen, P.E.; Burke, J.R.; Connolly, E.S., Jr.; Dunbar-Jacob, J.M.; Granieri, E.C.; McGarry, K.; et al. Risk factors and preventive interventions for Alzheimer disease: State of the science. Arch. Neurol. 2011, 68, 1185-1190. [CrossRef] [PubMed]

68. FAG de Bruijn, R.; Ikram, M.A. Cardiovascular risk factors and future risk of Alzheimer's disease. BMC Med. 2014, 12, 130. [CrossRef]

69. Wiciński, M.; Wódkiewicz, E.; Słupski, M.; Walczak, M.; Socha, M.; Malinowski, B.; Pawlak-Osińska, K. Neuroprotective activity of sitagliptin via reduction of neuroinflammation beyond the incretin effect: Focus on Alzheimer's disease. BioMed Res. Int. 2018, 2018, 6091014. [CrossRef]

70. Miranda, A.; Gómez-Gaete, C.; Mennickent, S. Role of Mediterranean diet on the prevention of Alzheimer disease. Rev. Med. Chil. 2017, 145, 501-507. [CrossRef]

71. Kerti, L.; Witte, AV.; Winkler, A.; Grittner, U.; Rujescu, D.; Flöel, A. Higher glucose levels associated with lower memory and reduced hippocampal microstructure. Neurology 2013, 81, 1746-1752. [CrossRef] [PubMed]

72. McNay, EC.; Fries, TM.; Gold, PE. Decreases in rat extracellular hippocampal glucose concentration associated with cognitive demand during a spatial task. Proc. Natl. Acad. Sci. USA 2000, 97, 2881-2885. [CrossRef] [PubMed]

73. Bhatt, J.K.; Thomas, S.; Nanjan, M.J. Resveratrol supplementation improves glycemic control in type 2 diabetes mellitus. Nutr. Res. 2012, 32, 537-541. [CrossRef] [PubMed]

74. Viollet, B.; Andreelli, F.; Jørgensen, S.B.; Perrin, C.; Geloen, A.; Flamez, D.; Mu, J.; Lenzner, C.; Baud, O.; Bennoun, M.; et al. The AMP-activated protein kinase alpha2 catalytic subunit controls whole-body insulin sensitivity. J. Clin. Investig. 2003, 111, 91-98. [CrossRef] [PubMed]

75. Um, J.H.; Park, S.J.; Kang, H.; Yang, S.; Foretz, M.; McBurney, M.W.; Kim, M.K.; Viollet, B.; Chung, J.H. AMP-Activated Protein Kinase-Deficient Mice Are Resistant to the Metabolic Effects of Resveratrol. Diabetes 2010, 59, 554-563. [CrossRef]

76. Fullerton, M.D.; Steinberg, G.R. SIRT1 takes a backseat to AMPK in the regulation of insulin sensitivity by resveratrol. Diabetes 2010, 59, 551-553. [CrossRef]

77. Ota, H.; Akishita, M.; Tani, H.; Tatefuji, T.; Ogawa, S.; Iijima, K.; Eto, M.; Shirasawa, T.; Ouchi, Y. Trans-Resveratrol in Gnetum gnemon protects against oxidative-stress-induced endothelial senescence. J. Nat. Prod. 2013, 76, 1242-1247. [CrossRef]

78. Kurokawa, S.; Berry, M.J. Selenium. Role of the essential metalloid in health. Met. Ions Life Sci. 2013, 13, 499-534.

79. Nazıroğlu, M.; Muhamad, S.; Pecze, L. Nanoparticles as potential clinical therapeutic agents in Alzheimer's disease: Focus on selenium nanoparticles. Expert Rev. Clin. Pharmacol. 2017, 10, 773-782. [CrossRef]

80. Benilova, I.; Karran, E.; De Strooper, B. The toxic A $\beta$ oligomer and Alzheimer's disease: An emperor in need of clothes. Nat. Neurosci. 2012, 15, 349-357. [CrossRef]

81. Wang, H.; Zhang, J.; Yu, H. Elemental selenium at nano size possesses lower toxicity without compromising the fundamental effect on selenoenzymes: Comparison with selenomethionine in mice. Free Radic. Biol. Med. 2007, 42, 1524-1533. [CrossRef] [PubMed]

82. Yin, T.; Yang, L.; Liu, Y.; Zhou, X.; Sun, J.; Liu, J. Sialic acid (SA)-modified selenium nanoparticles coated with a high blood-brain barrier permeability peptide-B6 peptide for potential use in Alzheimer's disease. Acta Biomater. 2015, 25, 172-183. [CrossRef] [PubMed] 
83. Zhang, J.; Zhou, X.; Yu, Q.; Yang, L.; Sun, D.; Zhou, Y.; Liu, J. Epigallocatechin-3-gallate (EGCG)-stabilized selenium nanoparticles coated with Tet-1 peptide to reduce amyloid- $\beta$ aggregation and cytotoxicity. ACS Appl. Mater. Interfaces 2014, 6, 8475-8487. [CrossRef] [PubMed]

84. Geng, J.; Li, M.; Ren, J.; Wang, E.; Qu, X. Polyoxometalates as inhibitors of the aggregation of amyloid $\beta$ peptides associated with Alzheimer's disease. Angew. Chem. Int. Ed. Engl. 2011, 50, 4184-4188. [CrossRef] [PubMed]

85. Neves, A.R.; Lúcio, M.; Martins, S.; Lima, J.L.S. Novel resveratrol nanodelivery systems based on lipid nanoparticles to enhance its oral bioavailability. Int. J. Nanomed. 2013, 8, 177-187.

86. Bush, A.I. Metals and neuroscience. Curr. Opin. Chem. Biol. 2000, 4, 184-191. [CrossRef]

87. Wang, W.; Chen, J.; Wang, N.; Zheng, G. A comparative study of resveratrol and resveratrol-functional selenium nanoparticles: Inhibiting amyloid $\beta$ aggregation and reactive oxygen species formation properties. J. Biomed. Mater. Res. A 2018, 106, 3034-3041.

88. Cavalli, A.; Bolognesi, L.M.; Minarini, A.; Rosini, M.; Tumiatti, V.; Recanatini, M.; Melchiorre, C. Multi-target-Directed Ligands To Combat Neurodegenerative Diseases. J. Med. Chem. 2008, 51, 347-372. [CrossRef]

89. Bonda, D.J.; Wang, X.; Perry, G.; Nunomura, A.; Tabaton, M.; Zhu, X.; Smith, M.A. Oxidative stress in Alzheimer disease: A possibility for prevention. Neuropharmacology 2010, 59, 290-294. [CrossRef]

90. Xu, P.; Zhang, M.; Sheng, R.; Ma, Y. Synthesis and biological evaluation of deferiprone-resveratrol hybrids as antioxidants, $A \beta_{1-42}$ aggregation inhibitors and metal-chelating agents for Alzheimer's disease. Eur. J. Med. Chem. 2017, 127, 174-186. [CrossRef]

91. Yang, X.; Qiang, X.; Li, Y.; Luo, L.; Xu, R.; Zheng, Y.; Cao, Z.; Tan, Z.; Deng, Y. Pyridoxine-resveratrol hybrids Mannich base derivatives as novel dual inhibitors of AChE and MAO-B with antioxidant and metal-chelating properties for the treatment of Alzheimer's disease. Bioorg. Chem. 2017, 71, 305-314. [CrossRef] [PubMed]

92. Jeřábek, J.; Uliassi, E.; Guidotti, L.; Korabecny, J.; Soukup, O.; Sepsova, V.; Hrabinova, M.; Kuca, K.; Bartolini, M.; Peña Altamira, L.E.; et al. Tacrine-resveratrol fused hybrids as multi-target-directed ligands against Alzheimer's disease. Eur. J. Med. Chem. 2017, 127, 250-262. [CrossRef] [PubMed]

93. Faden, A.I.; Wu, J.; Stoica, B.A.; Loane, D.J. Progressive inflammation-mediated neurodegeneration after traumatic brain or spinal cord injury. Br. J. Pharmacol. 2016, 173, 681-691. [CrossRef] [PubMed]

94. Suzuki, Y.; Brender, J.R.; Soper, M.T.; Krishnamoorthy, J.; Zhou, Y.; Ruotolo, B.T.; Kotov, N.A. Ramamoorthy Az Marsh ENG. Resolution of oligomeric species during the aggregation of A $\beta 1-40$ using (19)FNMR. Biochemistry 2013, 52, 1903-1912. [CrossRef]

95. Dong, J.; Atwood, C.S.; Anderson, V.E.; Siedlak, S.L.; Smith, M.A.; George Perry, A. Metal Binding and Oxidation of Amyloid- $\beta$ within Isolated Senile Plaque Cores: Raman Microscopic Evidence. Biochemistry 2003, 42, 2768-2773. [CrossRef] [PubMed]

96. Cheng, G.; Xu, P.; Zhang, M.; Chen, J.; Sheng, R.; Ma, Y. Resveratrol-maltol hybrids as multi-target-directed agents for Alzheimer's disease. Bioorg. Med. Chem. 2018, 26, 5759-5765. [CrossRef]

97. Kontoghiorghes, G.J.; Neocleous, K.; Kolnagou, A. Benefits and risks of deferiprone in iron overload in Thalassaemia and other conditions: Comparison of epidemiological and therapeutic aspects with deferoxamine. Drug Saf. 2003, 26, 553-584. [CrossRef]

98. Youdim, M.B.H. Monoamine oxidase inhibitors, and iron chelators in depressive illness and neurodegenerative diseases. J. Neural Transm. 2018, 125, 1719-1733. [CrossRef]

99. Drożak, J.; Kozłowski, M. Monoamine oxidase as a target for drug action. Postepy Hig. Med. Dosw. 2006, 60, 498-515.

100. Kato, H.; Samizo, M.; Kawabata, R.; Takano, F.; Ohta, T. Stilbenoids from the Melinjo (Gnetum gnemon L.) Fruit Modulate Cytokine Production in Murine Peyer's Patch Cells Ex Vivo. Planta Med. 2011, 77, 1027-1034. [CrossRef]

101. Yu, J.; Qi, J.; Zhang, L.; Yu, X.; Kong, Q.; Ren, X. Using the relative abundance of characteristic product ions in UHPLC-ESIQTOF-MS2 methods to identify isomers of resveratrol oligomers in extracts of Xinjiang winegrape stems. J. Chromatogr. B 2018, 1096, 88-94. [CrossRef] [PubMed]

102. Kato, E.; Tokunaga, Y.; Sakan, F. Stilbenoids isolated from the seeds of Melinjo (Gnetum gnemon L.) and their biological activity. J. Agric. Food Chem. 2009, 57, 2544-2549. [CrossRef] [PubMed] 
103. Tani, H.; Hikami, S.; Iizuna, S.; Yoshimatsu, M.; Asama, T.; Ota, H.; Kimura, Y.; Tatefuji, T.; Hashimoto, K.; Higaki, K. Pharmacokinetics and safety of resveratrol derivatives in humans after oral administration of melinjo (Gnetum gnemon L.) seed extract powder. J. Agric. Food Chem. 2014, 62, 1999-2007. [CrossRef] [PubMed]

104. Konno, H.; Kanai, Y.; Katagiri, M.; Watanabe, T.; Mori, A.; Ikuta, T.; Tani, H.; Fukushima, S.; Tatefuji, T.; Shirasawa, T. Melinjo (Gnetum gnemon L.) Seed Extract Decreases Serum Uric Acid Levels in Nonobese Japanese Males: A Randomized Controlled Study. Evid. Based Complement. Altern. Med. 2013, 2013, 589169. [CrossRef]

105. Espinoza, J.L.; Inaoka, P.T. Gnetin-C and other resveratrol oligomers with cancer chemopreventive potential. Ann. N. Y. Acad. Sci. 2017, 1403, 5-14. [CrossRef]

106. Kunimasa, K.; Ohta, T.; Tani, H.; Kato, E.; Eguchi, R.; Kaji, K.; Ikeda, K.; Mori, H.; Mori, M.; Tatefuji, T.; et al. Resveratrol derivative-rich melinjo (Gnetum gnemon L.) seed extract suppresses multiple angiogenesis-related endothelial cell functions and tumor angiogenesis. Mol. Nutr. Food Res. 2011, 55, 1730-1734. [CrossRef]

107. Kidger, A.M.; Sipthorp, J.; Cook, S.J. ERK1/2 inhibitors: New weapons to inhibit the RAS-regulated RAF-MEK1/2-ERK1/2 pathway. Pharmacol. Ther. 2018, 187, 45-60. [CrossRef]

108. Matsumiya, T.; Tanaka, H.; Hayakari, R.; Gnetin, C. A resveratrol dimer, reduces amyloid- $\beta$ 1-42 (A $\beta 42)$ production and ameliorates A $\beta 42$-lowered cell viability in cultured SH-SY5Y human neuroblastoma cells. Biomed. Res. 2018, 39, 105-115.

109. Ikuta, T.; Saito, S.; Tani, H.; Tatefuji, T.; Hashimoto, K. Resveratrol derivative-rich melinjo (Gnetum gnemon L.) seed extract improves obesity and survival of C57BL/6 mice fed a high-fat diet. Biosci. Biotechnol. Biochem. 2015, 79, 2044-2049. [CrossRef]

110. Nakagami, Y.; Suzuki, S.; Espinoza, J.L.; Vu Quang, L.; Enomoto, M.; Takasugi, S.; Nakamura, A.; Nakayama, T.; Tani, H.; Hanamura, I.; et al. Immunomodulatory and Metabolic Changes after Gnetin-C Supplementation in Humans. Nutrients 2019, 11, 1403. [CrossRef]

111. Espinoza, L.J.; An Thi, D.; Trung, Q.L.; Yamada, K.; Nakao, S.; Takami, A. Stilbene derivatives from melinjo extract have antioxidant and immune modulatory efects in healthy individuals. Integr. Mol. Med. 2015, 2, 405-413.

112. Walle, T.; Hsieh, F.; DeLegge, M.H.; Oatis, J.E., Jr.; Walle, U.K. High absorption but very low bioavailability of oral resveratrol in humans. Drug Metab. Dispos. 2004, 32, 1377-1382. [CrossRef] [PubMed]

113. Abd El-Mohsen, M.; Bayele, H.; Kuhnle, G.; Gibson, G.; Debnam, E.; Kaila Srai, S.; Rice-Evans, C.; Spencer, J.P. Distribution of $[3 \mathrm{H}]$ trans-resveratrol in rat tissues following oral administration. Br. J. Nutr. 2006, 96, 62-70. [CrossRef] [PubMed]

(C) 2020 by the authors. Licensee MDPI, Basel, Switzerland. This article is an open access article distributed under the terms and conditions of the Creative Commons Attribution (CC BY) license (http://creativecommons.org/licenses/by/4.0/). 